\title{
WESTERNISATION-INDIGENISATION IN SOCIAL WORK EDUCATION AND PRACTICE: UNDERSTANDING INDIGENISATION IN INTERNATIONAL SOCIAL WORK
}

\author{
BY SOMNOMA VALERIE OUEDRAOGO AND BARBARA WEDLER
}

\section{ABSTRACT}

International social work is about thinking globally when acting locally and vice-versa. Most of all, it is a field that requires acknowledging differences and a 'welcoming' of theories and practice models of one's own singularity (cultural, political, economic) for direction in understanding social work. These contextand population-specific approaches build the core identity of the social work profession. However, limited opportunity for these specific approaches, along with knowledge and skill gaps, underscore International Social Work post-secondary curriculum on a global scale. Thus, the authors are centrally concerned with conducting a research-informed study to strengthen International Social Work courses. In this article, the authors outline the development of Indigenisation theory and offer ways of thinking and interacting with social work concepts and methodologies in an International Social Work teaching and learning context. This article offers a pragmatic approach of considering a dialectic of Westernisation-Indigenisation, to connect the local and the global as well as the North and the South by aiming to develop the concept of Indigenisation in International Social Work. Through a tri-continental partnership (Europe, North America, Africa), the authors outline their current and future plans to create a research study to develop curriculum and conduct field work, to focus efforts on decolonizing social work practice and education. This partnership offers a two-directional relationship between global thinking and local acting, therefore modelling Indigenisation theory and its application on an international scale. 


\section{INTRODUCTION}

International Social Work was a term first used in 1928 that contextualized social work theory and practice within emerging trends in globalization. International Social Work encompasses scientific, economic, social, and environmental aspects of the profession that address policy, social justice and migration issues, as well as global social problems and international professional organizations of social work practice focused on the development of human rights. International social work practice includes comparative and global perspectives on each area of social work expertise and concern. Among these are the inability to care for the complex needs of children, individuals, families, and communities; poverty; cultural conflicts; and racial, ethnic, scientific, economic, social, and environmental oppression.

Decades ago, studies in International Social Work was a great knowledge gain for the profession (Healy, 1995). These studies reinforced the profession's beliefs and ethics of international human rights values for the profession itself and for the vulnerable and marginalized people of our society. Thanks to such studies, social work instructors, students, and practitioners learn and compare social work in different countries across the world (from the 'Global North' to 'Global South'), to nurture their inquiry about commonalities and differences in regard to social issues such as immigration and refugee work, poverty, addiction, and child and family welfare.

Current International Social Work practice tends to focus on cooperation for knowledge transfer and sharing professional experiences (Healy, 2002). However, this trend still follows colonial pathways. In Africa, for example, the development of social work is encouraged. Ironically, the training and education of African social workers continues the western knowledge and practice methods that mostly involve western faculties and expert staff (Kreitzer, 2012). Through the efforts of colleagues around the world, non-western methods, which have been used successfully since 1960 to fight poverty, unemployment, and hunger, are being attempted transferred into the western education and practice of social work (Lucas, 2013). When addressing the topic of International Social Work in the social work community, questions arise from reflection and debates about Imperialism, Universality, or Indigenisation (Gray, 2005; Midgley, 1981). Young scientists who are interested in this field of research (as we are as well), ask if there are any contradictions in the action 
of social work at this point. How can the challenges be identified or maintained with regard to communities, individuals, or families, if there is actual background knowledge on Indigenisation, for example? Practical work and theories of Social Work should be produced simultaneously through global networks of social work conferences, theories, and educational programs. At this time, it needs to be asked, which international globalization trends can be built up with this process?

\section{THE CONCEPT OF INDIGENISATION IN INTERNATIONAL SOCIAL WORK}

In this article, we will use the concept of Indigenisation, which has evolved from dialogues in the field of International Social Work, and will develop it further. The focus of our considerations are the global developments in the South, along with their local knowledge, theories, and practices. These developments should be integrated into western social work. The aim for the profession is to obtain a legitimation of this concept for a globalized social work.

The concept of Indigenisation is mainly found in research and literature in African social work (Mupedziswa, 2001; Osei Hwedie, 1996; Walton \& Abo E1 Nasr, 1988). It means a kind of adaptation, a process in which ideas, methods, and practices are adapted to local contexts. Added to this is the existing local knowledge and Indigenous resources, such as relationships and networks. Background, traditions, history, and values should also be understood along with ways to utilize them. In 1971, the Fifth United Nations International Survey used the debate on Indigenisation to argue the issue of relevance and inappropriateness of 'westernised' social work theories in other societies' programs (UN, 1971; Ugiagbe, 2015). Indigenisation therefore is characterized by the pertinence of social work and refers to a colonized process of adapting 'imported' ideas to fit local needs (Mupedziswa \& Sinkamba, 2014).

From a postcolonial approach, Indigenisation is about the decolonialization of social work. The process of this inquiry demands consciousness of a colonized 'mind' when developing social work's concepts and practices informed with socio-cultural, economical, political and environmental realities. This means an explicit awareness about social work in a context- and population-specific area that is leading the current practice of social work to a disconnect (from historical, cultural, and social relations) or ability to discover our ways of thinking and interrelationships with the world (Smith, 1999; Thiong'o, 1994). 
Indigenisation stands for a term that represents these different levels of separations (linguistic, historical, and social ways of thinking and relating to the world), in which the latest social work is operating. The current way of thinking and acting in social work is still too often legitimized by a 'West to the Rest' working attitude. Seeking to 'internationalize' and 'standardize' the profession (Akimoto, 2008) is jeopardizing the main relevance of International social work, which is the acknowledgement of differences in embracing the Indigenisation concept and strength-based approach by reflecting the 'client as expert perspective' in the development of the profession itself. Since these clients often become disconnected from context and populations, they are "people who have been subjected to colonialization and loss of sovereignty" (Smith, 1999, p.7). However, the clients seek to identify and maintain their particularities (worldview, language, ways of knowing) to reinforce the connectedness to their cultural, economical, and political context when utilizing social work services (Chitekereka, 2009). Rather than a total rejection of westernised social work heritage, social work education and practice in Global South-North discourse is looking for strength-based answers, practice, and theoretical models that will legitimate Indigenisation's values and ethics. By using an International social work perspective to develop the concept of Indigenisation, we will consider the dialectic of Westernisation-Indigenisation to connect the local and global as well as the North and South.

\section{METHODOLOGICAL CONSIDERATIONS - AN INTEGRATED APPROACH TO INTERNATIONAL SOCIAL WORK}

When thinking about methods in the profession of social work, we recognize the development of knowledge, skills, and abilities that will affect International social work tasks and activities. Cox and Pawar (2013) define International social work as the following:

The promotion of social work education and practice globally and locally, with the purpose of building a truly integrated international profession that reflects social work's capacity to respond appropriately and effectively, in education and practice terms, to the various global challenges that are having a significant impact on the well-being of large sections of the world's population. (Cox \& Pawar 2013, p.29-30) 
Cox and Pawar are thinking globally (context), based on human rights (values), in an ecological way (human-nature relationships) and want to empower social development (guide to action). These four interlinked perspectives are characterized by International social work as a so-called "integrated perspective approach" (Cox \& Pawar, 2013, p.30). According to the authors, each of the four perspectives above has an individual dimension, but at the same time they should be considered together. They also form the basis for our collaborative project between Germany, Canada, and Burkina Faso.

We support this integrated way of thinking and doing social work within an International social work field, that articulates the appropriateness and effectiveness of social work responses to the world's population. Therefore, we recommend connecting the local acting and the global thinking as well as the North and South in seeking to develop a concept of Indigenisation. This integrated theoretical and methodological perspective seems promising to our research study, because it helps us expose the dialectic Westernisation-Indigenisation in approaching Indigenisation as a global community movement named "Indigenousness" (Escárcega, 2010). Acknowledging this perspective in our study prompts us to question the appropriateness and efficiency of the scientific, practice-oriented discipline of social work education.

\section{DEVELOPMENT OF A RESEARCH QUESTION}

The number of international students taking social work training in western universities is increasing (Chowa, Danso, \& Sherradan, 2007). It is impossible to go through this experience without a continuous reflective attitude (particularly intellectual in my case) towards identifying oneself with social work theories and practices. Unfortunately, many social workers around the globe are taught to think and do social work at a distance from and even against their own 'culture' (e.g., lacking a sense of local circumstances, language, collective memories, and histories). They seem to be disconnected from their own ways of thinking and relating to the world.

When Ouedraogo began developing a course on International social work for MacEwan School of Social Work, she came across the use of the integrated-perspective approach of Cox and Pawar (2013) in considering, learning, and teaching International social work as both a concept and practice of social work. Coming across this insight opens the possibility for her to inquire about 
non-westernised ways of knowing and doing social work. Moreover, it allows her to explore the reproduction of westernised knowledge domination and power imbalance in regard to non-westernised ways of knowing (Ouedraogo, 2014). By developing a concept of Indigenisation in International social work, our collaborative project about Westernisation-Indigenisation aims to answer the following research question: What can social work in Germany and Canada learn from social work in Burkina Faso?

\section{DEVELOPMENT OF THE COLLABORATIVE PROJECT}

In 2017, we began the first phase of our collaborative project by launching a seminar titled "International Social Work" in order to develop an epistemological understanding of International social work in the context of Germany and Canada. In critical appraisal, students questioned the accuracy and accountability of the contemporary social work education they were receiving and practicing. In conclusion, the students emphasized that the "colonization in the head"(Straub, 2016), which is observable as a concomitant of globalization in social work, has led to student demand for more courses on international influences on social work.

Based on a research-informed teaching approach, this project will involve faculty and students from the University of Mittweida (Germany) and MacEwan University (Canada) as well as social work professionals in Ouagadougou (Burkina Faso).

\section{MAIN IDEAS OF OUR COLLABORATIVE PROJECT - INDIGENISATION IN INTERNATIONAL SOCIAL WORK CURRICULUM}

The majority of our project is related to the seminar course titled "International Social Work." In preparation of designing a research study, we decided to look at International social work as a promotion of social work education and the global and local practices in Germany, Canada, and Burkina Faso. The study will focus on the Westernisation-Indigenisation process of social work in these countries.

The main learning outcome of this collaborative project is to develop a concept of Indigenisation. In theory and practice, Indigenisation should shape 
sustainable thinking and action in social work. Thus, we intend to study the following questions: How is the concept of Indigenisation created? How does participating in this activity flow into the concept of Indigenisation? How does this result in a learning outcome? By addressing these questions, we can develop a module at the end of this project as part of an International Social Work course that focuses on the following questions: What are the specialties in terms of social work in an international context? What opportunities for learning arise from this module?

\section{INTENTION OF THE COLLABORATIVE PROJECT}

When considering social work in a global context, the clarification of key concepts is a general requirement to creating transparency about content and understanding. With a changed view of the world and the global context of local problems, a change of language usage also has begun. Industrial nations and developing countries are increasingly becoming the Global South and the Global North. Behind these terms are various social, political, and economic positions. Likewise, these also include various experiences with colonialism and exploitation. Even if a large geographical orientation is associated with North and South, these terms are less a definition than a dynamic framework that requires individual consideration of countries and Indigenous peoples at different levels. According to the Human Development Report (2016), Germany and Canada are assigned to the Global North and considered to be high developed countries; whereas, Burkina Faso is assigned to the Global South and considered to be the fourth lowest developed country.

Thus, the purpose of this project is to bring students in contact with research and transnational experiences to develop knowledge, skills, and abilities related to the international influences of globalization. These experiences are the driving forces in the development of the social work profession. Our idea is to reverse the flow of the collaboration, by first exploring the Indigenisation process in Canada and Germany to develop an understanding of Indigenisation in a 'Global North' context. Then we will open up a dialogue about social work in Burkina Faso. The idea behind this approach is to learn about Social Work education and practice, as well as to explore the place, role, and meaning of Indigenisation in a 'Global South' context. 
Students will be involved in data collection and analysis, study tours, field placement in partner countries, and presentations to research showcases. These studies and long-term partnerships will connect students with topics they will likely experience in their future working experience. Participating social work students will be better positioned to understand International social work holistically, and participate in critical, meaningful dialogue surrounding the limitations of western knowledge, skills, and values that inform contemporary social work training and practice in an increasing globalized worldview.

\section{THREE PHASES OF THE COLLABORATIVE PROJECT}

The first phase of the project was the analysis of social work developments in Europe and North America. This process was accompanied by a review of literature, lectures, and seminars on Indigenisation in an International social work context. This phase has already taken place at MacEwan University in Edmonton (Canada) and at the University of Applied Sciences in Mittweida (Germany). During the second phase of the project, which is still in development, an epistemological understanding and practice of Indigenisation in International Social Work will be compared in the context of Germany and Canada. Innovative in this perspective is to explore Indigenisation in a Global North context to focus more on special features and opportunities that will result through this research-informed teaching approach under consideration.

Field work in the third country, Burkina Faso, will take place during the third phase, to examine Indigenisation through the knowledge, skills, and abilities (in curricula and practice) in social work within an African context. Students, educators and practitioners in Burkina Faso will be involved in the development of the International social work course as guest lecturers, to share experiences, knowledge, skills, and case studies from their context. At the end of the third phase, the findings and analysis of our collaborative study will be developed in preparation for a book publication by the participating faculties.

It is our hope to build further collaboration between Burkina Faso, Canada, and Germany, which will permit further research-informed teaching in International social work courses or seminars. This partnership will also support field work, study tours, and field placements occurring in three continents: Africa, Europe, and North America. This means that we are interested 
in bringing research and teaching together as a key to inquiry-based learning. Due to the relevance of social work in an international context, the authors set themselves the goal of developing a module and later a degree course in International social work at the three participating universities, situated in three separate continents.

\section{INTERNATIONALIZATION OF SOCIAL WORK SEMINAR AT THE UNIVERSITY OF MITTWEIDA [GERMANY]}

From September 2016 to February 2017, the "Internationalization of Social Work" seminar addressed the developments of social work in relation to local political developments in Germany. In view of global problems and local differences, as we articulated in the previous section of this chapter, a first seminar was offered as a kind of "test run" at the University of Applied Sciences in Mittweida. As part of the module "Social Work Discourses" in the master's program "Social Work," a topic entitled "Indigenisation in Social Work" was offered and discussed. The aim of this topic was to develop an epistemological understanding of International social work in the context of the two countries Burkina Faso and the Federal Republic of Germany. The choice fell on the two countries for this first study program, because the North - South problematic could be exemplified.

By the end of the seminar, students were expected to recognize and evaluate the national challenges of social work in the context of international developments. The cooperation between the three countries and continents will therefore lead to a critical examination of Indigenisation in International social work.

\section{SEMINAR CONTENT}

The "Internationalization of Social Work" seminar focused on international influences on the national-state dimension of social action (Friesenhahn, 2002) and on Straub's (2016) perspective of "colonialisation in the mind" that can be observed as an accompaniment to globalization in social work. Indigenous approaches described as "Indigenisation in the Social Work of the Global South" to help, support, and heal have been increasingly forgotten in the focus 
of professional work. With the "Internationalization of Social Work" seminar, international topics in social work were addressed and discussed in the context of a specific background (Canada-North America, Burkina Faso-West Africa, as well as Federal Republic of Germany-Central Europe):

- Internationalization of social work on a global scale

- Involvement of "pre-professional" approaches in the development of professions

- Social Work of the South and the North / West

- Indigenised and Indigenous social work

- Westernization-Indigenisation in social work

This content was compiled from the perspective of the respective countries and compared through professional discourses.

\section{SEMINAR DELIVERY}

In the seminars, students were encouraged through readings, class discussions, and group work to look at social issues from the perspective of others (people, professionals, countries) and to develop an understanding of the specific situations of social work in other countries and continents. At the same time, critical analyses of Indigenous approaches were examined in intersection with classical social work through readings, in-class discussions, group work, and lecturing.

Based on the results of Bertelsmann's (2016) study, "Globalization Fear or Value Conflict?," a research report on the perception of globalization from EU-citizens, a thesis that globalization processes also influence social work, was introduced to initiate an in-class discussion. This activity was supported by lecturing that emphasized how social work in the three selected countries were impacted by globalization. In small group work, the students collected information on the (social) political situation of the respective countries and, thanks also to the media exchange with colleagues from the respective countries, compiled an overview of the status of social work as a profession. Generally speaking, the result of the discussions, lecturing, and group work was a shift in perspective from the negative consequences (imperialistic expansion of 
social work profession) to the positive aspects of globalization, especially Indigenisation as a common local characteristic when considering a global definition of social work. Through discussions, students voiced how local Indigenous communities and peoples are responding to changes through their own discussions and memories about how they experience the disconnect of the social work profession from their own worldviews.

\section{SEMINAR KEY INSIGHTS}

During students' critical inquiry process, they examined how social work is taught and practiced. There were three main reflection points: (1) Local Indigenous communities respond promptly to the standardised way of thinking and doing social work in calling for more context (historical, social, economical, political, cultural) around ways of thinking and doing social work. (2) This call to action can be a useful complement and even a professional shift to the technocratic and neo-liberal approach in European, 'westernised,' social work. (3) In considering this shift in Germany, the Sorbs were identified as an Indigenous group that might lead or be representative of this call to focus on the local and be connected to the global.

In terms of content, students conducted literature research to present during the seminar. They developed three main themes from their literature research: (1) The national development of social work (especially in the USA and pre- and post-war Germany). Students explored the establishment of international organizations or umbrella organizations of social work and the "colonization" of social work. (2) The generalization of social work. Students addressed the dimensions of Westernization and Global Ethics in International social work. (3) The global definition of social work to understand definitions of International social work. Students nourished their inquiry by focusing on diversity, structures, political dimension, social work science as practice-oriented science, culture as construct, and Indigenous knowledge in International social work.

Students completed individual preliminary work on the three main themes by preparing two questions, each of which was discussed in groups. The first question explored the universality of social work theories (to what extent are the theories of social work universal?), and the second question focused on 
Indigenous approaches such as "healing" and "development." The latter topic, in particular, points to meaningful developments within social work and global issues. "Healing" shows the extension or improvement of social, cultural, political, economical, community-related, and self-related humility as well as intercultural knowledge, skills, and relationship building among the seminar participants. Through the critical examination of readings, in-class discussions, and group work, students identified resiliency and identity as key dimensions of "healing" (Sautermeister, 2018). In fact, "healing" was a process within this collaboration (group work), community of learners (in-class discussions), and sense-making (readings and lecturing). The healing process created a common ground for students to recognize that others from their point of view can be extended to the recognition of the 'Indigenisation' (local) into the 'International Social Work' (global). The focus on self-healing, thanks to a close connection to nature and community in the sense of collective memories, worldviews, and histories (Thiong'o, 1994), was named in the seminar reflection as an important "aha" effect. Equally important was the evolving issue of Indigenous resources in the immediate area and relationship proximity (in Saxony), and the question of why the knowledge of Indigenous peoples was ignored and forgotten. At the end of the seminar, students described the open discussion as a call to greater attention to Indigenous approaches and an opportunity to counter neoliberal developments with the evolving stance of openness.

As the seminar focused on international influences on the nation-state dimension of social action, we observed both individual and collective insights: (1) A student reported his experiences from the insight gained through the individual work and group discussions on Westernisation. He reflected on the local knowledge of social workers regarding social work methods in parallel to his role as an expert with western knowledge. (2) In dealing with the concept of Indigenous identity, a student reflected more broadly on the dimension of Indigenisation and acknowledged the presence of Indigenous peoples in Europe, and even near the university's location, the Sorbs. (3) Through discussion on social work in Africa, especially in Burkina Faso, students jointly created the main research question: How can Indigenous knowledge and traditions enrich the education and practice of social work at the University of Applied Sciences in Mittweida? 


\section{SEMINAR EVALUATION}

The evaluation of the seminar produced two main findings. On the one hand, the semester length was considered far too short for this topic. The various theories could only be outlined and sometimes only named. On the other hand, this seminar broadened their perspective of Indigenous peoples, Indigenous knowledge, and the various forms of their exclusion and oppression.

Unfortunately, within the confines of one semester, only the understanding of social work which can be 'globally thought' and 'locally acted' could be expanded upon. But the "test run” seminar awoke students' curiosity to inquire more on Indigenisation in social work in the International social work context and to experiment the transferability of ideas and knowledge developed during the semester. We observed that the desire for something new, for these other facets of basic social work, also resulted in students proactively asking for a mandatory course on International social work at the Faculty of Social Work at the University of Applied Sciences of Mittweida.

\section{INTERNATIONAL SOCIAL WORK COURSE AT MACEWAN UNIVERSITY [CANADA]}

MacEwan University's School of Social Work is located in Edmonton, Alberta. MacEwan University as a whole is located on the traditional territories of the people of the Treaty 6 region in Central Alberta, which is called Amiskwaciy Waskahikan or Beaver Hill House in Nehiyawewin (Cree). This is the traditional home of the Nehiyaw (Cree) and Michif (Métis), and a meeting place for many Indigenous peoples including the Nakawe (Saulteaux), Siksika (Blackfoot), Nakota Sioux (Stoney), and other nations. We assume this makes MacEwan University a meaningful place to initiate our collaborative project. This part of the project will explore social work education and practice in Burkina Faso and from there, an inquiry as to how social work in the 'Global North' can learn from social work in the 'Global South.'

After offering a two-year diploma program for 40 years, the School of Social Work responded to the province's needs and expanded (since September 2016) to a Bachelor's degree with a focus on Indigenous ways of knowing, Sustainability, and Internationalisation as new challenges for social work edu- 
cation and practice. This particular degree takes into account the influences of national and international trends within its curriculum. Concretely, this means building the curriculum around Canadian Indigenous ways of knowing and international issues that influence training and practice. Canada is a nation on a journey of reconciliation with its Indigenous heritage, and reinforcing its hospitality in regard to a growing immigrant population to better the country's demographic and economic growth.

Social Work in Canada is therefore recognizing people "who have been subjected to colonialization and loss of sovereignty" (Smith, 1999). These are people who experience internal colonialization, are Indigenous peoples, and are the original people of the Americas, including people who have been labelled by various governments as American Indian, Native Hawaiian, First Nations, Inuit, Aboriginal, and Métis (Tamburro, 2013). There are also those who share a collective memory of external colonization; they are new Canadians (immigrants and refugees) from African backgrounds representing the generation of settlers who came after the first main known from French and British background.

\section{COURSE CONTEXT}

The course on International Social Work, which is still in the development process, will provide students with a comprehensive introduction to International social work and integrated perspectives approaches (Cox \& Pawar, 2013) that blend globalization, human rights, and ecological and social development theories. Under the main themes of globalization, it will cover theories underpinning International social work history and the current realities of the global profession: global ethics; global policy by exploring international social work practice with particular attention to health and mental health; children and families; urban Indigenous people; social and environmental sustainability; and community work in local, national, and international settings.

\section{PROPOSED COURSE CONTENT}

The content of this course will focus on the challenges that nations across the world face in improving the lives of their citizens given current economic, 
social, political, and environmental circumstances. The course will identify the diverse strategies and skills that social workers across the world are using collaboratively to build a model of practice. The course will be offered in six-block classes in a blended format (online and in-class). The following themes will be addressed in the course content to cover the 13 weeks required:

- History, values, beliefs, and goals of International social work practice

- Global North, Global South, Global, and International

- Contextualizing International social work practice

- Theoretical perspectives in international social work practice (modernization, globalization, internationalization, transnationalism, multiculturalism, interculturality, universality, social development, and sustainable development)

- Human rights, social justice, and social change

- The United Nations and Non-Governmental Organizations

- Work and families in the context of globalization

- Children, women, immigrants, and Indigenous issues

- Social Relief International

- International social service organizations

- Social work education and social work practice (country specific)

- International field placements

The course will explore ways in which micro and macro skills can be integrated via a social and sustainable development model for interventions in international settings. A major focus will be on the enhancement of knowledge and skills, in order to better comprehend the development, implementation, and evaluation of International social work practice. We will attempt to reverse the flow of knowledge from "developing” ('Global South') to "developed” or ('Global North') nations by incorporating readings, group discussions, individual research and presentations, and case studies that will enhance collaborative learning between and within the students from the three continents involved in the collaborative teaching and research project.

Like we attempted in Germany, we aim for this course to be offered at an undergraduate level of social work to explore critical analyses of Indigenous approaches, while also examining the intersection to classical social work. At the end of the course, students will be able to recognize and evaluate the national challenges of social work in the context of international develop- 
ments. The cooperation between the three countries and continents will therefore lead to a critical examination on Indigenisation in social work, as well as the development of a module on Indigenisation in the International social work context to complete International social work Module in the Schools of Social Work in the three countries.

\section{TOWARDS A MUTUAL LEARNING APPROACH THROUGH TEACHING AND RESEARCH}

In this section we are tying back our perspective of a mutual learning to the proposed research question: What can social work in Germany and Canada learn from social work in Burkina Faso?

In Germany, there is a general and comprehensive document called the "Qualifications Framework Social Work - Version 6.0” (Schäfer \& Bartosch, 2016). This document describes formal aspects and competencies for the study of social work while also underlining the attitude, personality, and application of theoretical knowledge in social work practice. It is considered to be the basis for promoting a "sense of action, judgment and critical reflection" to social work in general (Schäfer \& Bartosch, 2016, p.14).

This general qualification document opens up the opportunity to look at social work globally within a local context. An example of Europe-wide changes in the education and research process is the Bologna Process, which is a view of social work expanding towards an international dimension (Lutz \& Wagner, 2009). There is also the case of social work education and practice in Africa which, without denying its colonial heritage vis à vis its education curricula and practice, is looking after this connectedness to this postcolonial context (Osei-Hwedie, 1993). Social work is a science and profession that can influence social, political, and economic processes in global developments, because social work gives a voice to those who cannot rise for themselves (Lutz \& Wagner, 2009, p.9). For example, in Burkina Faso or Canada, students, researchers, educators, and practitioners not only come together during the learning process, but also bring with them other ways of life, problem-solving strategies, life experiences, forms of coexistence, etc. Together, they are forced to deal with the new and the "own" in teaching and learning social work.

We assume that our project represents what Lutz and Wagner (2009) describe as the point of development for social work as both a science and a 
profession. Learning from the South (to resume the next phase of our project) therefore means first being able to reflect on oneself and to see the close and covert entanglement in one's own ways of knowing and doing social work (Rehklau \& Lutz, 2009, p.52). From our perspective regarding indigenisation in the international social work context, one's view of one's self is sharpened if one looks at another and it turns out that there is not the social work. Since international comparisons show that the forms of social work in the 'Global South,' as in Burkina Faso, are often colonial-structural in nature, recent efforts have been made to decode these outdated concepts and initiate autochthonous development (Schnurer, 2008).

Therefore, an exchange at the level of practical experience is unproblematic due to the official language of French in Burkina Faso and English in Edmonton, Canada, which allows actual practice in Burkina Faso and also in Canada. If exchange of practice supplements the doctrine, it is possible to experience differences between the Global South and the North, to nurture our thoughts and inquiries during the project implementation. Mutual recognition and respect for each other are more likely to develop together, to enhance teaching and learning in a mutual exchange: "Developments on the autonomy. . .the recognition of the other, of the good life and the chances of realization. . .can be combined under the term of indigenisation, which grew out of the independent discourses in these countries [of the Global South]" (Ruhklau \& Lutz, 2009, p.42).

Our field work and local research in Burkina Faso will help us explore and understand the indigenisation processes, which will then be applied to social work education and practice. This combination of teaching and practice as a research-informed teaching exercise, will also promote the research process to understand the forces of the indigenisation process in the Global North (Germany-Canada) as well as exploring and understanding local research with regard to indigenous processes in Burkina Faso. Our exercise can support all three countries in their own understanding of their social work education and practice (articulate the particularities of the local) and reinforce their interconnectedness (be aware about the specificities of the global). Our grassroots work will lay a foundation for networks that meet local conditions and integrate teaching and research taking place globally, for example, by incorporating indigenous ways of knowing and teaching materials. In such a teaching and learning situation, a joint (mutual) research activity is conceivable (Ruhklau \& Lutz, 2009). 


\section{ACKNOWLEDGEMENT:}

Some content of this article was presented at the $4^{\text {th }}$ International Indigenous Social Work Conference, 11-14 June 2017, in Alta/Norway. We acknowledge the Grant of the Faculty of Health and Community Studies as well as the School of Social Work of MacEwan University from where we received support for this scholarly activity.

\section{REFERENCES}

Akimoto, T. (2008). What is International Social Work? Its contribution to social work in a global society. Paper given at the Symposium of the $100^{\text {th }}$ Anniversary of the Alice Salomon Hochschule Berlin. https:/www.ash-berlin.eu/100-JahreASH/symposium/doc/3_5_akimoto.pdf

Chitereka, C. (2009). Social Work Practice in a developing continent. The Case of Africa, Advances in Social Work, 10(2), 144-156. https://doi.org/10.18060/223

Chowa, G., Danso, K., \& Sherraden, M. (2007). Under-utilized contributions by international students: Case study for education and research. CSD Working Papers, 7(20), 1-12.

Cox, D., \& Pawar, M. (2012). International social work: Issues, strategies, and programs. Thousand Oaks, CA: Sage. https://doi.org/10.4135/9781544308685

Escárcega, S. (2010). Authenticating strategic essentialisms: The politics of Indigenousness at the United Nations. Cultural Dynamics, 22(1), 3-28. https://doi.org/10.1177/0921374010366780

Friesenhahn, G. J. (2002). Zwischen Empowerment und Kundenorientierung: Die internationale/interkulturelle Dimension in der Ausbildung für Soziale Professionen. In S. Elsen, G. J., Friesenhahn, \& W. Lorenz (Eds.), Für ein Soziales Europa: Ausbilden-Lehren-Handeln in Sozialen Professionen, 123-143. Mainz: Logophon Verlag.

Gray, M. (2005). Dilemmas of international social work: Paradoxical processes in Indigenisation, universalism and imperialism. International Journal of Social Welfare, 14(2), 230-237. https://doi.org/10.1111/j.1468-2397.2005.00363.x

Gray, M., \& Fook, J. (2004). The quest for a universal Social Work: Some issues and implications. Social Work Education, 23(5), 625-644. https://doi.org/10.1080/0261547042000252334 
Healy, L. (2002). International Social Work. New York: Oxford University Press.

Healy, L. (1995). Comparative and international overview. In T. D. Watts, D.

Elliott \& N. Mayadas (Eds.), International Handbook on Social Work Education, 421-440. Westport, CT: Greenwood Press.

Kreitzer, L. (2012). Social Work in Africa: Exploring culturally relevant education and practice in Ghana. Calgary: University of Calgary Press.

https://doi.org/10.2307/j.ctv6gqws2

Lucas, T. (2013). Social Work in Africa: The imperative for social justice, human rights, and peace. Botswana Journal of African Studies, 27(1), 87-106.

Lutz, R., \& Wagner, L. (2009). Internationale Perspektiven für die Soziale Arbeit, Einleitung. In Lutz, R. and Wagner, L (Eds.), Internationale Perspektiven für die Soziale Arbeit, Einleitung. Dimensionen - Themen - Organisationen ( $\left.2^{\text {nd }} \mathrm{ed}.\right)$ Hrsg.). Wiesbaden: VS Verlag für Sozialwissenschaften. https://doi.org/10.1007/978-3-531-91760-3_1

Midgley, J. (1981). Professional imperialism: Social work in the Third World. London: Heinemann.

Mupedziswa, R., \& Sinkamba, R. P. (2014). Social work education and training in southern and east Africa: Yesterday, today and tomorrow. In C. Noble, H. Strauss, B. Littlechild (Eds.), Global Social Work: Crossing Borders, Blurring Boundaries. Sydney University Press.

Mupedziswa, R. (2001). The quest for relevance: Towards a conceptual model of developmental social work education and training in Africa. International Social Work, 44(3), 285-300. https://doi.org/10.1177/002087280104400302

Tamburro, A. (2013). Including decolonization in Social Work education and practice. Journal of Indigenous Social Development, 2(1), 1-16.

Ouedraogo, S. V. (2014). Chercheurs de « l'entre-deux »-Travailleurs sociaux dans le rôle de chercheurs: Proximité et distance d'une ethnographie interpretative, Fractal. Rev. Psicol., 26(3), 765-784. https://doi.org/10.1590/1984-0292/1334

Osei-Hwedie, K. (1993). The challenge of Social Work in Africa: Starting the Indigenisation process. Journal of Social Development in Africa, 8(1), 19-30.

Osei-Hwedie, K. (1996). The Indigenization of Social Work education and practice in Africa: The dilemma of theory and method. Social Work Maatskaplike Werk, 32(3), 215-225.

Rehklau, Chr., \& Lutz, R. (2009). Sozialarbeit des Südens. Entwicklung und Befreiung. In H.G Homfeldt, \& C. Reutlinger (Eds.), Soziale Arbeit und Soziale Entwicklung: Grundlagen der Sozialen Arbeit (Bd. 20). Baltmannsweiler: Schneider Verlag Hoghengehren. 
Sautermeister, J. (2018). Selbstgestaltung und Sinnsuche unter fragilen Bedingungen. Moralpsychologischen und ethische Anmerkungen zum Verhältnis von Resilienz und Identität. In: M. Karidi, M. Schneider, R. Gutwald (Eds.), Resilienz. Interdisziplinäre Perspektiven zu Wandel und Transformation. Wiesbaden GmbH: Springer, 127-140.

https://doi.org/10.1007/978-3-658-19222-8_7

Schäfer, P., \& Bartosch, U. (2016). Qualifikationsrabmen Soziale Arbeit (QR

SozArb, Version 6.0), Fachbereichstag Soziale Arbeit, Würzburg. http://www.fbts.de/fileadmin/fbts/QR_SozArb_Version_6.0.pdf

Schnurer,J. (2008). Rezension vom 06.01.2008 zu: Rehklau, C. and Lutz, R. (2009), Sozialarbeit des Südens.: Zugänge (Bd 1). Oldenburg: Paolo Freire Verlag. In: socialnet Rezensionen, ISS 2190-9245. http://socialnet.de/ rezensionen/5681.php

Smith, L. T. (1999). Decolonising Methodologies. Dunedin: University of Otago Press.

Straub, U. (2016). "All my relations" - indigene Ansätze und Relationalität in der Sozialen Arbeit, In F. Früchtel, \& M. Strassner (Eds.), Relationale Sozialarbeit - versammelnde, vernetzende und kooperative Hilfeformen. Weinheim: BeltzJuventa.

Thiong', N. (1994). Decolonizing the mind: The politics of language in African literature. Oxford: James Currey.

Ugiagbe, E. O. (2015). Social work is context-bound: The need for Indigenization of social work practice in Nigeria. International Social Work, 58(6) 790 -801. https://doi.org/10.1177/0020872813515013

United Nations. (1971). Training for social welfare: Fifth International Survey. New Approaches in Meeting Manpower Needs. United Nations, New York, N.Y. Dept. of Economic and Social Affairs. ED 067 316, 1971. Retrieved from https:// eric.ed.gov/?id=ED067316

Walton, R. G., \& Abo E1 Nasr, M. M. (1988). Indigenization and authentization in terms of social work in Egypt. International Social Work, 31(2), 135-144. https://doi.org/10.1177/002087288803100207 